\title{
Effect of Fly Ash, Organic Manure and Fertilizers on Soil Microbial Activity in Rice-Wheat Cropping System in Alfisols and Vertisols
}

\author{
L.K. Ramteke, S.S. Sengar and S.S. Porte* \\ Department of Soil Science and Agricultural Chemistry, IGKV, Raipur (C.G), India \\ *Corresponding author
}

\author{
A B S T R A C T
}

\section{Keywords}

Fly ash, Microbial activity, Ricewheat cropping system.

Article Info

Accepted:

21 June 2017

Available Online:

10 July 2017
Field experiment was conducted under Alfisols at KVK, Farm Katghora, Korba and Vertisols at Instructional Farm Indira Gandhi Krishi Vishwavidyalaya, Raipur during 2011,2012and2013.To assess the effect of different doses of fly ash alone or in combination with manure and fertilizers in rice -wheat cropping system with Sixteen treatments (i.e. $\mathrm{T}_{1}$ Control, $\mathrm{T}_{2}-10 \mathrm{t}$ FA ha ${ }^{-1}, \mathrm{~T}_{3}-20 \mathrm{t} \mathrm{FA} \mathrm{ha}^{-1} \mathrm{~T}_{4}$ STCR (based fertilizer recommendation), $\mathrm{T}_{5-7} 75 \mathrm{NPK} \mathrm{ha}^{-1}, \mathrm{~T}_{6-1} 100 \% \mathrm{NPK}(100: 60: 40), \mathrm{T}_{7-75} \% \mathrm{NPK} \mathrm{ha}^{-1}+10 \mathrm{t}$ FA ha ${ }^{-1}, \mathrm{~T}_{8-} 75 \% \mathrm{NPK} \mathrm{ha}^{-1}+20 \mathrm{t} \mathrm{FA} \mathrm{ha}^{-1}, \mathrm{~T}_{9} 100 \% \mathrm{NPK} \mathrm{ha}^{-1}+10 \mathrm{t} \mathrm{FA} \mathrm{ha}^{-1}, \mathrm{~T}_{10-1} 100 \%$ NPK ha ${ }^{-1}+20$ t FA ha $^{-1}, \mathrm{~T}_{11-} 75 \% \mathrm{NPK} \mathrm{ha}^{-1}+5 \mathrm{t} \mathrm{FYM} \mathrm{ha}^{-1}, \mathrm{~T}_{12}$.100\% $\mathrm{NPK} \mathrm{ha}^{-1}+5$ t FYM $\mathrm{ha}^{-1}, \mathrm{~T}_{13-} 75 \% \mathrm{NPK} \mathrm{ha}^{-1}+5 \mathrm{t} \mathrm{FYM}^{-10} \mathrm{t}$ FA, $\mathrm{T}_{14-} 75 \% \mathrm{NPK} \mathrm{ha}^{-1}+5 \mathrm{t}$ FYM +20 t FA ha ${ }^{1}, \mathrm{~T}_{15-100} \% \mathrm{NPK} \mathrm{ha}^{-1}+5 \mathrm{t} \mathrm{FYM}^{-10} \mathrm{t} \mathrm{FA} \mathrm{ha}^{-1}$ and $\mathrm{T}_{16-} 100 \% \mathrm{NPK} \mathrm{ha}^{-1}+5 \mathrm{t} \mathrm{FYM+20} \mathrm{t}$ FA ha ${ }^{-1}$ ) under Split Plot Design with factorial arrangment of crop and soil in main plot and treatment in sub plot.The microbial biomass carbon and dehydrogenase activity in soil at harvest of crops was significantly increased due to addition of fly ash and FYM in ricewheat cropping system in Alfisol and Vertisol. The treatment, $\mathrm{T}_{16}$ recorded highest microbial biomass carbon and dehydrogenase activity during the year 2011, 2012 and pooled data. The interaction of crop $\mathrm{x}$ soil $\mathrm{x}$ treatments was non-significant

\section{Introduction}

Fly ash is an amorphous ferroalumino silicate, Physically fly ash occurs as fine particles (60$70 \%$ ) which has a size below $0.075 \mathrm{~mm}$, it is a by-product of pulverized coal fired thermal power station and has low to medium bulk density, high surface area and very light texture with $\mathrm{pH}$ varying from 4.5 to 12 depending upon sulphur content in the coal (Lal et al., 2012). In India and most of the other countries major source of electrical energy is coal based thermal power plants, which produce 175 million tonnes, fly ash which would require about 40,000 hectares of land for the construction of ash ponds (Lal et al., 2012). The ash production in India is expected to reach about 225 million tonnes per annum by 2017.

The Ministry of Power and Planning Commission estimates that the coal requirement and generation of fly ash during the year 2031-32 would be around 1800 million tonnes and 600 million tonnes respectively (Kanungo, 2013). The fly ash utilization in the country is estimated to be about 59\% only (Kanungo, 2013). Eleven major Thermal Power Plants in Chhattisgarh which produces fly ash to the tone of about 
26880 metric tones per day i.e. nearly 9.7 million tones of fly ash annually, out of which the four major Thermal Power Plants in Korba district alone generate about 24000 metric tones per day.

This is nearly $90 \%$ of the total ash generated in the state and about $8.7 \%$ of the total ash generated in the country.

The microbial activity in soil increases due to addition of fly ash and organic matter and consequently provided sufficient nutrition for the proliferation of microbes.

Lal et al., (1996) reported that application of fly ash in presence of FYM to an acid soil (Alfisols) resulted in increased microbial population, urease and cellulose activities than alone.

Sarangi et al., (2001) reported that invertase, amylase, dehyrogenase and protease activity increased with increasing application of fly ash up to $15 \mathrm{t}_{\text {ha }} \mathrm{y}^{-1}$.

The dehydrogenase activity in soil was determined by method given by Klein et al., (1971).

Biomass carbon was determined by the fumigation extraction method as per the procedure of Jenkison and Powlson (1976).

\section{Microbial biomass carbon}

Table 1 shows that microbial biomass carbon in soil at harvest of crops was significantly increased due to addition of fly ash and FYM in rice-wheat cropping system in Alfisol and Vertisol.

The higher microbial biomass carbon recorded in rice and wheat under Vertisol during 2011, 2012 and pooled data.
Table 2 shows that the treatment, $\mathrm{T}_{16}$ recorded highest microbial biomass carbon during the year 2011, 2012 and pooled data. The lowest microbial biomass carbon was recorded in $\mathrm{T}_{1}$. The interaction of crop $\mathrm{x}$ soil $\mathrm{x}$ treatments was non-significant.

\section{Dehydrogenase activity}

Table 1 shows that dehydrogenase activity in soil at harvest of the crop significantly increased due to addition of fly ash and FYM in rice-wheat cropping system in Alfisol and Vertisol.

The higher dehydrogenase activity was recorded in wheat under Vertisol during 2011$12,2012-13$ and pooled data.

Table 3 shows that the treatment; $\mathrm{T}_{16}$ recorded higher dehydrogenase activity in 2011, 2012 and pooled data. It was at par with treatment, $\mathrm{T}_{15}$ and $\mathrm{T}_{14}$ in 2011, and $\mathrm{T}_{15}$ in 2012 and pooled data. The lowest dehydrogenase activity was recorded in treatment, $\mathrm{T}_{1}$. The interaction of crop x soil $\mathrm{x}$ treatments.

Microbial activity significantly increased with application of fly ash alone or in combination with organic manure and fertilizer as compared to control.

These results might be due to the fact that applied organic sources were able to get mineralized rapidly and consequently provided sufficient nutrition for the proliferation of microbes and their activities in terms of soil enzymes.

Addition of organic sources acts as good sources of carbon and energy to heterotrophs by which their population increased with an increase in enzyme activities. Similar results were also reported by Jala (2005) and Kohli et al., (2010). 
Table.1 Effect of fly ash alone or in combination with organic manure and fertilizers on microbial activity in soil in

Rice-wheat cropping system in Alfisol and Vertisol at harvest

\begin{tabular}{|c|c|c|c|c|c|c|c|c|c|c|c|c|}
\hline \multirow[t]{3}{*}{ Particular } & \multicolumn{6}{|c|}{ Microbial biomass carbon (ppm) } & \multicolumn{6}{|c|}{ Dehydrogenase activity (Mg of TPF produced/g soil/ha) } \\
\hline & \multicolumn{2}{|c|}{2011} & \multicolumn{2}{|c|}{2012} & \multicolumn{2}{|c|}{ Pooled } & \multicolumn{2}{|c|}{2011} & \multicolumn{2}{|c|}{2012} & \multicolumn{2}{|c|}{ Pooled } \\
\hline & Vertisol & Alfisol & Vertisol & Alfisol & Vertisol & Alfisol & Vertisol & Alfisol & Vertisol & Alfisol & Vertisol & Alfisol \\
\hline Rice & 214.50 & 168.70 & 214.50 & 168.03 & 214.50 & 168.37 & 4.05 & 3.60 & 4.05 & 3.63 & 4.06 & 3.61 \\
\hline \multirow[t]{2}{*}{ Wheat } & 200.88 & 165.61 & 201.42 & 166.60 & 201.65 & 167.23 & 4.23 & 3.90 & 4.35 & 3.95 & 4.29 & 3.92 \\
\hline & SEm \pm & $\begin{array}{c}\text { CD at } \\
5 \%\end{array}$ & SEm \pm & $\mathrm{CD}$ at $5 \%$ & $\mathrm{SEm} \pm$ & $\mathrm{CD}$ at $5 \%$ & SEm \pm & $\begin{array}{c}\text { CD at } \\
5 \%\end{array}$ & SEm \pm & $\mathrm{CD}$ at $5 \%$ & SEm \pm & $\begin{array}{c}\mathrm{CD} \text { at } \\
5 \%\end{array}$ \\
\hline A & 0.642 & 2.217 & 0.540 & 1.862 & 0.562 & 1.940 & 0.025 & 0.088 & 0.024 & 0.084 & 0.023 & 0.080 \\
\hline B & 0.642 & 2.217 & 0.540 & 1.862 & 0.562 & 1.940 & 0.025 & 0.088 & 0.024 & 0.084 & 0.023 & 0.080 \\
\hline $\mathrm{A} \times \mathrm{B}$ & 0.908 & 3.135 & 0.763 & 2.634 & 0.795 & 2.743 & 0.036 & N/A & 0.034 & 0.119 & 0.033 & N/A \\
\hline
\end{tabular}

Table.2 Effect of fly ash alone or in combination with organic manure and fertilizers on microbial biomass carbon in

Rice-wheat cropping system in Alfisol and Vertisol at harvest

\begin{tabular}{|c|c|c|c|c|c|c|c|}
\hline \multirow{2}{*}{\multicolumn{2}{|c|}{ Treatments }} & \multicolumn{6}{|c|}{ Microbial biomass carbon (in ppm) } \\
\hline & & \multicolumn{2}{|c|}{2011} & \multicolumn{2}{|c|}{2012} & \multicolumn{2}{|c|}{ Pooled } \\
\hline $\mathrm{T}_{1}$ & - Control & \multicolumn{2}{|c|}{113.80} & \multicolumn{2}{|c|}{115.25} & \multicolumn{2}{|c|}{112.59} \\
\hline $\mathrm{T}_{2}$ & $-10 \mathrm{t} \mathrm{FA} \mathrm{ha}^{-1}$ & \multicolumn{2}{|c|}{123.24} & \multicolumn{2}{|c|}{125.57} & \multicolumn{2}{|c|}{124.60} \\
\hline $\mathrm{T}_{3}$ & $-20 \mathrm{t} \mathrm{FA} \mathrm{ha}^{-1}$ & \multicolumn{2}{|c|}{139.43} & \multicolumn{2}{|c|}{138.56} & \multicolumn{2}{|c|}{138.87} \\
\hline $\mathrm{T}_{4}$ & - STCR & \multicolumn{2}{|c|}{176.75} & \multicolumn{2}{|c|}{173.99} & \multicolumn{2}{|c|}{175.67} \\
\hline $\mathrm{T}_{5}$ & $-75 \% \mathrm{NPK}_{\mathrm{ha}}^{-1}$ & \multicolumn{2}{|c|}{171.44} & \multicolumn{2}{|c|}{168.14} & \multicolumn{2}{|c|}{169.06} \\
\hline $\mathrm{T}_{6}$ & $-100 \% \mathrm{NPK} \mathrm{ha}^{-1}$ & \multicolumn{2}{|c|}{188.98} & \multicolumn{2}{|c|}{188.42} & \multicolumn{2}{|c|}{188.31} \\
\hline $\mathrm{T}_{7}$ & $-75 \%$ NPK ha ${ }^{-1}+10$ t FA ha $^{-1}$ & \multicolumn{2}{|c|}{180.14} & \multicolumn{2}{|c|}{179.72} & \multicolumn{2}{|c|}{180.34} \\
\hline $\mathrm{T}_{8}$ & $-75 \%$ NPK ha ${ }^{-1}+20 \mathrm{t} \mathrm{FA} \mathrm{ha}^{-1}$ & \multicolumn{2}{|c|}{184.03} & \multicolumn{2}{|c|}{185.01} & \multicolumn{2}{|c|}{184.29} \\
\hline $\mathrm{T}_{9}$ & - $100 \%$ NPK ha ${ }^{-1}+10$ t FA ha $^{-1}$ & \multicolumn{2}{|c|}{194.69} & \multicolumn{2}{|c|}{194.25} & \multicolumn{2}{|c|}{194.21} \\
\hline $\mathrm{T}_{10}$ & $-100 \%$ NPK ha ${ }^{-1}+20$ t FA ha $^{-1}$ & \multicolumn{2}{|c|}{202.42} & \multicolumn{2}{|c|}{201.13} & & \\
\hline $\mathrm{T}_{11}$ & - $75 \%$ NPK ha ${ }^{-1}+5$ t FYM ha ${ }^{-1}$ & & & & & & \\
\hline $\mathrm{T}_{12}$ & $-100 \% \mathrm{NPK} \mathrm{ha}^{-1}+5 \mathrm{t} \mathrm{FYM} \mathrm{ha}^{-1}$ & & & & & & \\
\hline $\mathrm{T}_{13}$ & $-75 \%$ NPK ha ${ }^{-1}+5$ t FYM+10 t FA ha $^{-1}$ & & & & & & \\
\hline $\mathrm{T}_{14}$ & $-75 \%$ NPK ha ${ }^{-1}+5$ t FYM+20 t FA ha & & & & & & \\
\hline $\mathrm{T}_{15}$ & $-100 \% \mathrm{NPKha}^{-1}+5$ t FYM+10 t FA ha ${ }^{-1}$ & & & & & & \\
\hline $\mathrm{T}_{16}$ & 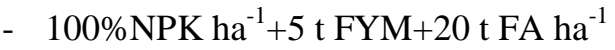 & & & & & & \\
\hline & & SEm \pm & $\mathrm{CD}$ at $5 \%$ & $\mathrm{SEm} \pm$ & $\mathrm{CD}$ at $5 \%$ & $\mathrm{SEm} \pm$ & $\mathrm{CD}$ at $5 \%$ \\
\hline $\mathrm{C}$ & & 1.49 & 4.19 & 1.44 & 4.03 & 1.34 & 3.76 \\
\hline $\mathrm{A} \times \mathrm{C}$ & & 2.12 & 5.93 & 2.04 & $\mathrm{~N} / \mathrm{A}$ & 1.90 & N/A \\
\hline $\mathrm{B} \times \mathrm{C}$ & & 2.12 & 5.93 & 2.04 & 5.71 & 1.90 & 5.32 \\
\hline
\end{tabular}


Int.J.Curr.Microbiol.App.Sci (2017) 6(7): 1948-1952

Table.3 Effect of fly ash alone or in combination with organic manure and fertilizers on dehydrogenase activity in Rice-wheat cropping system in Alfisol and Vertisol at harvest

\begin{tabular}{|c|c|c|c|c|c|c|}
\hline \multirow[t]{2}{*}{ Treatments } & \multicolumn{6}{|c|}{ Dehydrogenase activity (mg of TPF produced/g soil/h) } \\
\hline & \multicolumn{2}{|c|}{2011} & \multicolumn{2}{|c|}{2012} & \multicolumn{2}{|c|}{ Pooled } \\
\hline $\mathrm{T}_{1}-$ Control & \multicolumn{2}{|c|}{2.69} & \multicolumn{2}{|c|}{2.66} & \multicolumn{2}{|c|}{2.67} \\
\hline $\mathrm{T}_{2}-10 \mathrm{t} \mathrm{FA} \mathrm{ha}^{-1}$ & \multicolumn{2}{|c|}{$3.43^{\mathrm{i}}$} & \multicolumn{2}{|c|}{3.43} & \multicolumn{2}{|c|}{3.43} \\
\hline $\mathrm{T}_{3}-20 \mathrm{t} \mathrm{FA} \mathrm{ha}^{-1}$ & \multicolumn{2}{|c|}{$3.60^{\mathrm{h}}$} & \multicolumn{2}{|c|}{3.65} & \multicolumn{2}{|c|}{3.62} \\
\hline $\mathrm{T}_{4}-\mathrm{STCR}$ & \multicolumn{2}{|c|}{$3.87^{\mathrm{f}}$} & \multicolumn{2}{|c|}{3.90} & \multicolumn{2}{|c|}{3.88} \\
\hline $\mathrm{T}_{5}-75 \% \mathrm{NPK} \mathrm{ha}^{-1}$ & \multicolumn{2}{|c|}{$3.70^{\mathrm{g}}$} & \multicolumn{2}{|c|}{3.75} & \multicolumn{2}{|c|}{3.72} \\
\hline $\mathrm{T}_{6}-100 \% \mathrm{NPK} \mathrm{ha}{ }^{-1}$ & \multicolumn{2}{|c|}{$3.82^{\mathrm{f}}$} & \multicolumn{2}{|c|}{3.84} & \multicolumn{2}{|c|}{3.83} \\
\hline $\mathrm{T}_{7}-75 \% \mathrm{NPK} \mathrm{ha}^{-1}+10 \mathrm{tFA} \mathrm{ha}^{-1}$ & \multicolumn{2}{|c|}{$3.81^{\mathrm{f}}$} & \multicolumn{2}{|c|}{3.85} & \multicolumn{2}{|c|}{3.83} \\
\hline $\mathrm{T}_{8}-75 \% \mathrm{NPK} \mathrm{ha}^{-1}+20 \mathrm{t} \mathrm{FA} \mathrm{ha}^{-1}$ & \multicolumn{2}{|c|}{$3.91^{\mathrm{e}}$} & \multicolumn{2}{|c|}{3.87} & \multicolumn{2}{|c|}{3.89} \\
\hline $\mathrm{T}_{9}-100 \% \mathrm{NPK} \mathrm{ha}^{-1}+10 \mathrm{t} \mathrm{FA} \mathrm{ha}^{-1}$ & \multicolumn{2}{|c|}{$4.09^{\mathrm{d}}$} & \multicolumn{2}{|c|}{4.11} & \multicolumn{2}{|c|}{$4.10^{\mathrm{e}}$} \\
\hline $\mathrm{T}_{10}-100 \% \mathrm{NPK} \mathrm{ha}^{-1}+20 \mathrm{tFA} \mathrm{ha}^{-1}$ & \multicolumn{2}{|c|}{$4.19^{c}$} & \multicolumn{2}{|c|}{4.29} & \multicolumn{2}{|c|}{$4.24^{\mathrm{d}}$} \\
\hline $\mathrm{T}_{11}-75 \% \mathrm{NPK} \mathrm{ha}^{-1}+5 \mathrm{tFYM} \mathrm{ha}^{-1}$ & & & & & & \\
\hline $\mathrm{T}_{12}-100 \%$ NPK ha ${ }^{-1}+5 \mathrm{t} \mathrm{FYM} \mathrm{ha}^{-1}$ & & & & & & \\
\hline $\mathrm{T}_{13}-75 \% \mathrm{NPK} \mathrm{ha}^{-1}+5 \mathrm{t}$ FYM $+10 \mathrm{tFA} \mathrm{ha}^{-1}$ & & & & & & \\
\hline $\mathrm{T}_{14}-75 \% \mathrm{NPK} \mathrm{ha}^{-1}+5 \mathrm{t} \mathrm{FYM}+20 \mathrm{tFA} \mathrm{ha}^{-1}$ & & & & & & \\
\hline $\mathrm{T}_{15}-100 \% \mathrm{NPKha}^{-1}+5 \mathrm{t} \mathrm{FYM}+10 \mathrm{t} \mathrm{FA} \mathrm{ha}^{-1}$ & & & & & & \\
\hline $\mathrm{T}_{16}-100 \% \mathrm{NPK} \mathrm{ha}^{-1}+5 \mathrm{t} \mathrm{FYM}+20 \mathrm{t} \mathrm{FA} \mathrm{ha}^{-1}$ & & & & & & \\
\hline & $\mathrm{SEm} \pm$ & $\mathrm{CD}$ at $5 \%$ & $\mathrm{SEm} \pm$ & $\mathrm{CD}$ at $5 \%$ & SEm \pm & $\mathrm{CD}$ at $5 \%$ \\
\hline $\mathrm{C}$ & 0.045 & 0.125 & 0.040 & 0.112 & 0.036 & 0.100 \\
\hline $\mathrm{A} \times \mathrm{C}$ & 0.063 & 0.177 & 0.057 & 0.159 & 0.050 & 0.141 \\
\hline $\mathrm{B} \times \mathrm{C}$ & 0.063 & 0.177 & 0.057 & 0.159 & 0.050 & 0.141 \\
\hline
\end{tabular}




\section{References}

Jala, S. and Goel, D. 2006. Fly ash as a soil ameliorant for improving crop production-a review. Bioresourse Technology. 97:1136-1147.

Jankinson, D.S. and Powlson, D.S. 1976. The effect of biocidal treatment on soil. VAmethod for measuring soil biomass. Soil Boil. Biochem. 8:209-213.

Kanungo, S.P. 2013. Laboratory studies and field application of fly ash in forest nurseriesand plantation at CSIRIMMT, National workshop on use of fly ash in forestry and development of degraded/ wasteland, held during sept. 12-13, 2013, pp- 23-33.

Klein, D. A., Loh, T.C. and Coudling, R.L. 1971. A rapid procedure to evaluate dehydrogenase activity of soils low in organic matter. Soil Biol. Biochem. 385387.
Kohli, S.J. and Goyal, D. 2010. Effect of fly ash application on some soil physicalproperties and microbial activities. Acta Agrophysica 16 (22), 327-335.

Lal, J.K., Mishra, B. and Sarkar, A.K, 1996. Effect of fly ash on soil microbial and enzymatic activity. J. Indian Soc.Soil Sci., 44(1): 77-80.

Lal, K., Chhabra, R., Mongia, A.D. Meena, R.L. and Yadav, R.K. 2012. Release and uptake of potasium and sodium with fly ash application in rice on reclaimed alkali soil. Journal of the Indian Society of Soil Science 60, 181186.

Sarangi, P.K. Mahakur, D. and Mishra, P.C. 2001. Soil biochemical activity and and growth response of rice Oryza Sativa in fly ash amended soil. Bioresour. Technol. (76): 199-205.

\section{How to cite this article:}

Ramteke, L.K., S.S. Sengar and Porte, S.S. 2017. Effect of Fly Ash, Organic Manure and Fertilizers on Soil Microbial Activity in Rice-Wheat Cropping System in Alfisols and Vertisols. Int.J.Curr.Microbiol.App.Sci. 6(7): 1948-1952. doi: https://doi.org/10.20546/ijcmas.2017.607.231 